\title{
A SAMPLE OF PREY REMAINS FOUND IN GREAT-HORNED OWL NESTS IN SASKATCHEWAN IN 2008
}

MARTIN GERARD, \#91 Caron Cr., Saskatoon, SK, S7T 1A8, E-mail: <saskgerards@hotmail.com>; JARED B. CLARKE, \#3-2144 Rose St., Regina, SK, S4P 2A4; KELLY KOZIJ, 803 Coteau Ave., Weyburn, SK, S4H OH1; and DAN ZAZELENCHUK, Box 39, Kyle, SK, SOL 1 T0.

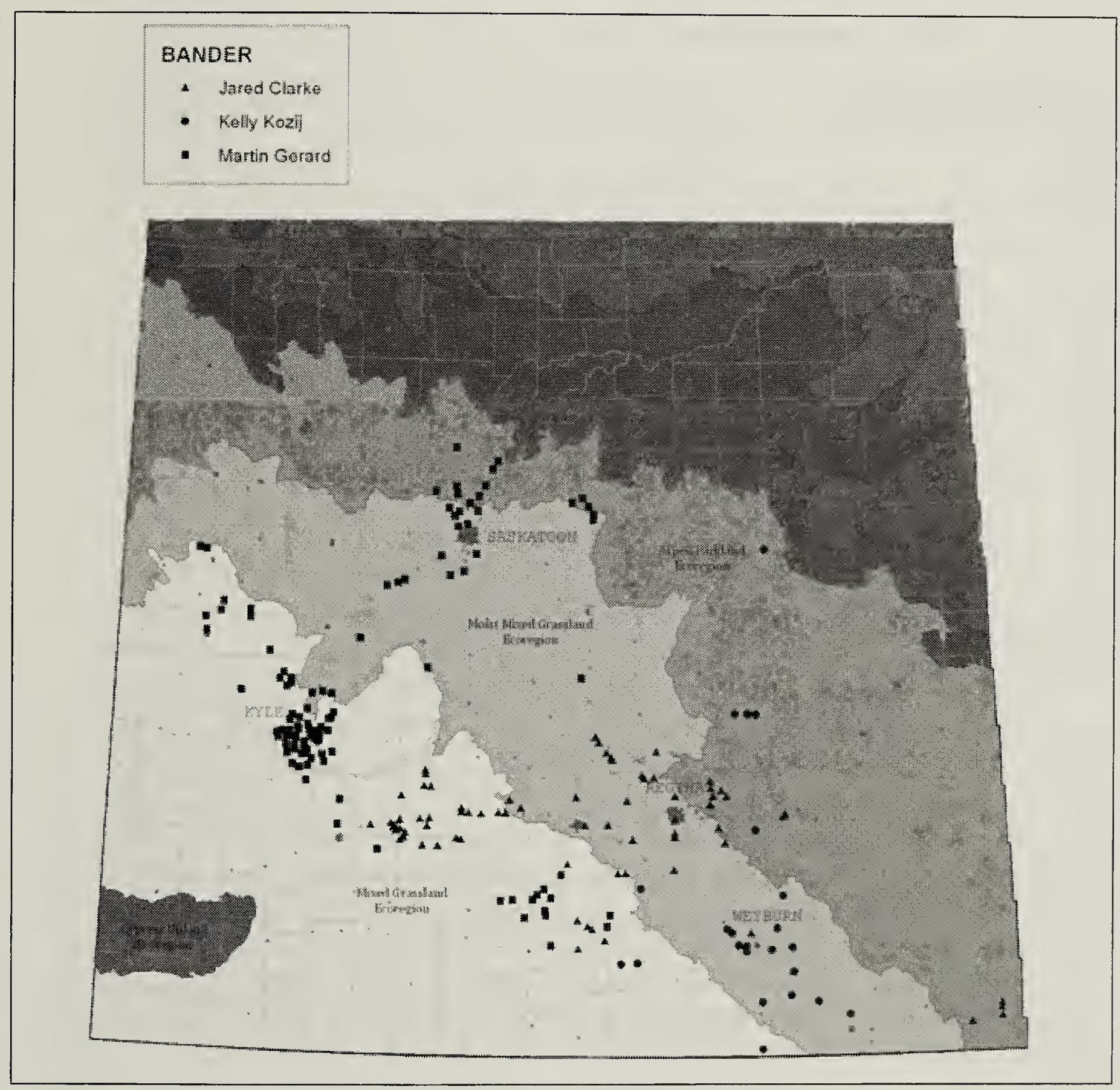

Figure 1. Locations of GHOW nesting sites visited in Southern Saskatchewan in 2008.

Ray Poulin

We visited 210 Saskatchewan Greathorned Owl (GHOW) nesting sites between 27 April and 3 July 2008 (Fig. 1). Our objectives were to: (a) band the young, (b) identify trends in the types of nesting trees or other structures selected by owls, and (c) to document aspects of GHOW diet by examining prey remains.

GHOW nesting habitats varied widely, as would be expected for a 
species that opportunistically uses nests of other birds. In the Aspen Parkland surrounding Saskatoon, Trembling Aspen (Populus tremuloides) predominated as nest trees, while in the farmyards in the Kyle region, Manchurian EIm (Ulmus laciniata) and Ash were more commonly used. Also represented, in order of frequency, were Manitoba Maple (Acer negundo), hybrid poplar
(Populus sp.), White Spruce (Picea glauca), Eastern Cottonwood (Populus deltoides), American EIm (UImus americana), willow (Salix sp.), and Balsam Poplar (Populus balsamifera) (Table 1). Eight nests were in manmade structures: five barns, a wooden box in a spruce, a basket in a spruce, and one on a tire mounted on a 3-m pole.

\section{Table 1. Great-horned Owl nest sites.}

\begin{tabular}{|l|l|l|}
\hline \# nests banded at & Tree species & $\%$ of total \\
\hline 25 & Ash & 11.9 \\
\hline 66 & Trembling Aspen & 31.4 \\
\hline 5 & Balsam Poplar & 2.4 \\
\hline 10 & Eastern Cottonwood & 4.8 \\
\hline 9 & American Elm & 4.3 \\
\hline 31 & Manchurian Elm & 14.8 \\
\hline 19 & Manitoba Maple & 9 \\
\hline 18 & Hybrid poplar & 8.6 \\
\hline 15 & Spruce & 7.1 \\
\hline 6 & Willow & 2.9 \\
\hline 5 & Barn & 2.4 \\
\hline 1 & Tire on post & 0.5 \\
\hline Total 210 & & \\
\hline
\end{tabular}

Food items recovered from $\mathrm{GHOW}$ nests also varied widely. Of the 210 nests, 82 had no food, and at 21 others, food data were unavailable, predominantly owing to poor climbing conditions. American Coot (14.7\%) and Gray Partridge (5.2\%) were the most abundant bird species found (Table 2). Two nests contained Burrowing Owls, three had Longeared Owls, three had Short-eared Owls, one had an American Kestrel, and one contained Northern Harrier feathers. Remains of adult and young GHOW, Cooper's Hawks, Red-tailed Hawks, Swainson's Hawks, and Merlins have also all been found in Saskatchewan GHOW nests in previous years (unpublished data). Northern Pocket Gophers and Deer Mice were the most common mammalian prey species $(10.8 \%$ and $8.6 \%$ of total individual prey items, respectively; see Fig. 2, inside front cover). Other numerous prey items included waterfowl, lagomorphs (rabbits and hares), and various rodent species. In total, 35 species of birds (127 items) and 13 species of mammals (102 items) were identified. One reptile, a garter snake (likely Thamnophis radix), was also found. Regurgitated pellets that contained Giant Water Bug (Lethocerus americanus) shells were found at two nests.

We used time-lapse photography to identify prey items in one GHOW nest near Yellow Grass from 1840h on 6 May to 1920 h on 12 May. We took 648 photographs at 15 -minute intervals. 


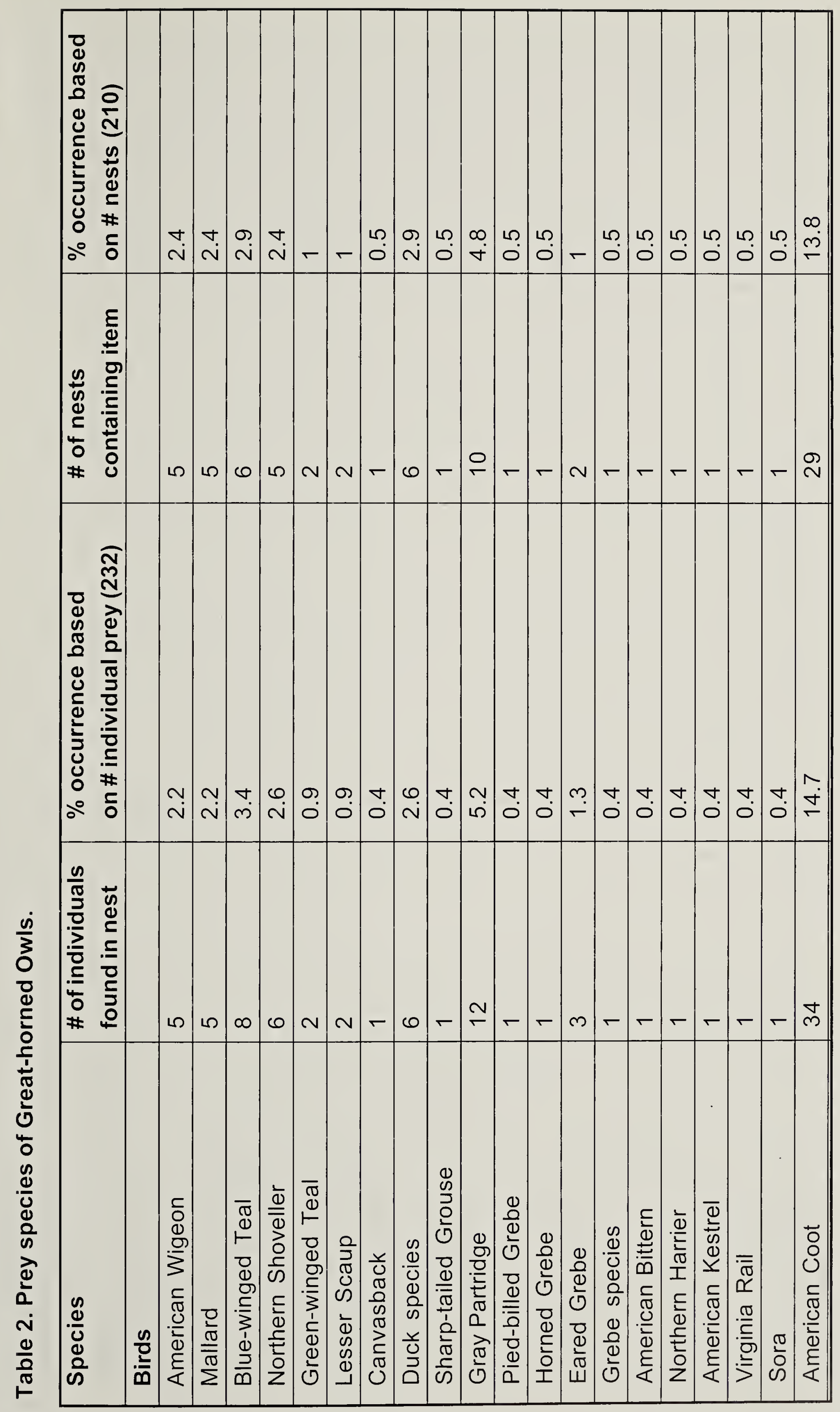




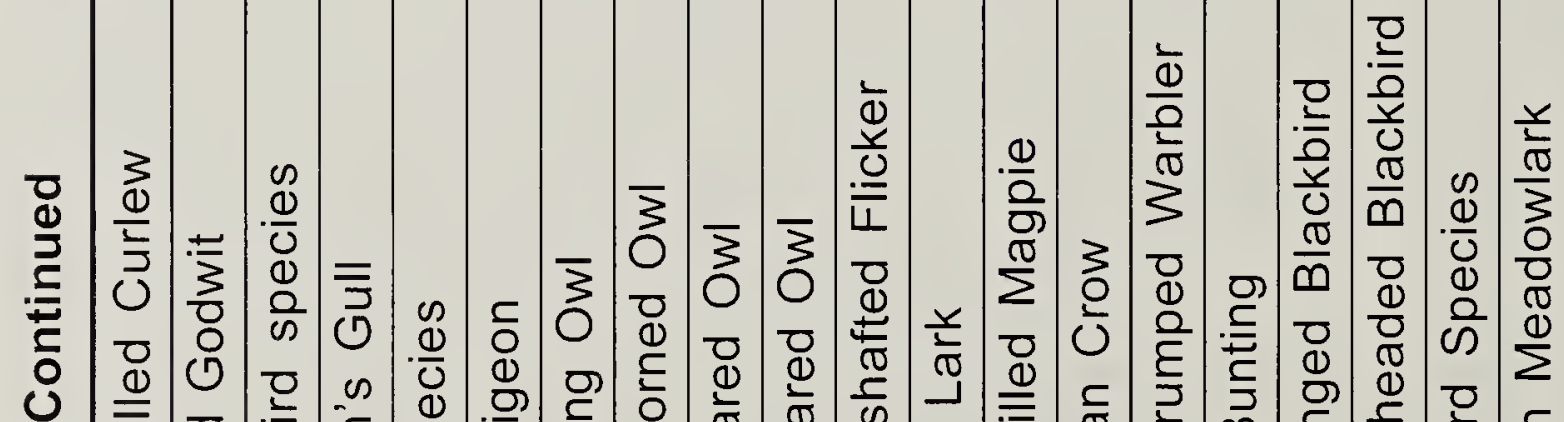

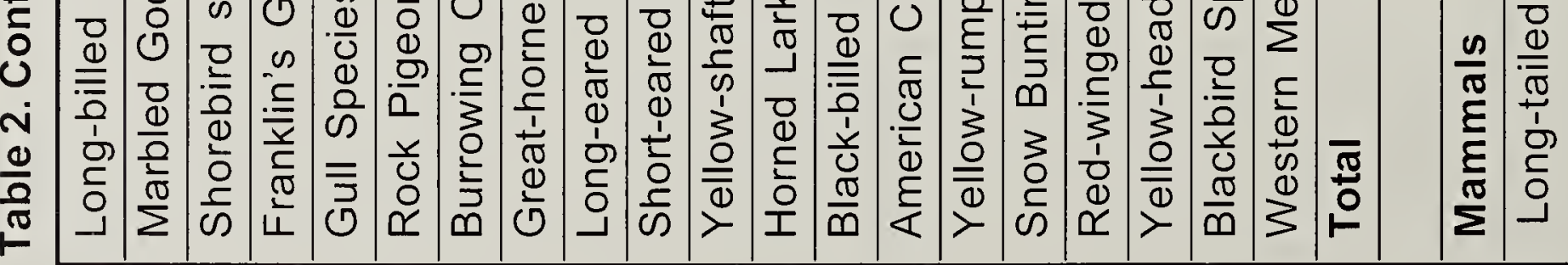




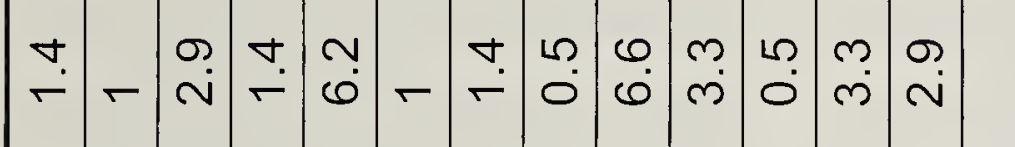

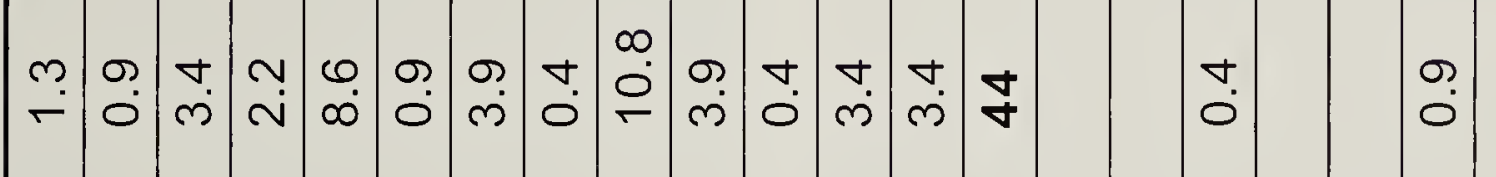

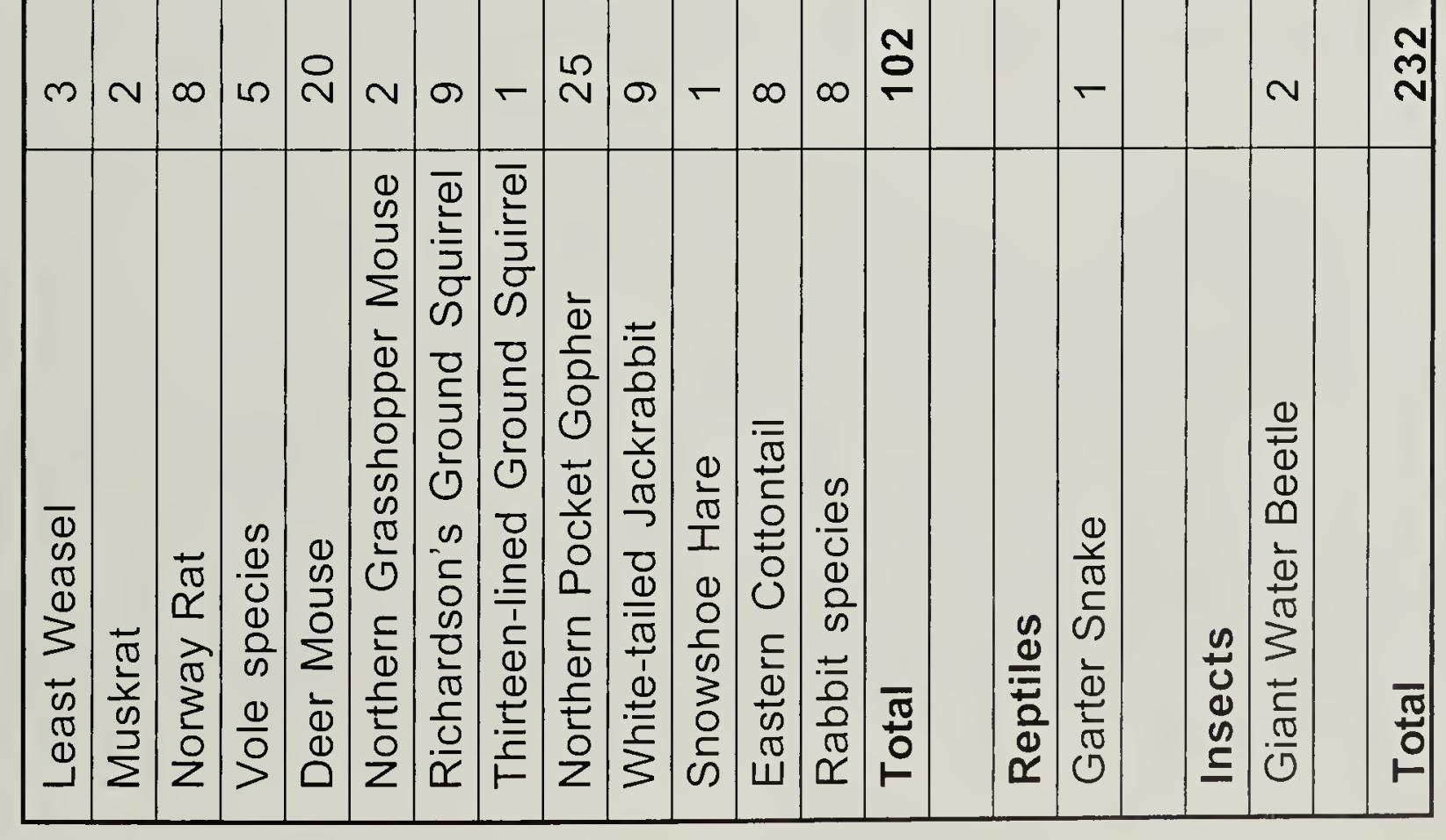




\begin{tabular}{|c|c|c|c|c|}
\hline Year & Norway Rats & Weasels & \begin{tabular}{|l} 
Burrowing Owls \\
\end{tabular} & Nests Visited \\
\hline 2000 & $2(2.3 \%)$ & $1(1.1 \%)$ & 0 & 88 \\
\hline 2001 & 0 & 0 & 0 & 43 \\
\hline 2002 & 0 & 0 & 0 & 76 \\
\hline 2003 & $1(1.0 \%)$ & 0 & 0 & 101 \\
\hline 2004 & 0 & 0 & 0 & 113 \\
\hline 2005 & $3(2.4 \%)$ & $1(0.8 \%)$ & 0 & 124 \\
\hline 2006 & $3(4.5 \%)$ & 0 & 0 & 66 \\
\hline 2007 & $1(1.8 \%)$ & 0 & 0 & 55 \\
\hline Totals & $10(1.3 \%)$ & $2(0.25 \%)$ & 0 & 790 \\
\hline 2008 & $6(2.9 \%)$ & $4(1.9 \%)$ & $2(1.0 \%)$ & 210 \\
\hline
\end{tabular}

The following prey items were photographed: Jack Rabbit, Deer Mouse, Thirteen-lined Ground Squirrel, vole, blackbird, Richardson's Ground Squirrel, male Blue-winged Teal, and Muskrat.

Norway Rats, weasels, and Burrowing Owls seemed to be represented in greater than usual numbers. Because of this, field data were reviewed for the years 2000 to 2007 (Table 3). It must be noted, however, that yearly sampling effort and surveyed regions vary. Also, in 2008, the data pooled the efforts of three banders, resulting in a much larger sample size and a much broader geographical area than in previous years.

One of the two nests at which Burrowing Owls were found as prey was an artificial platform (a tire on a post) less than $1 \mathrm{mi}$ from an active Burrowing Owl colony. When we "enhance" habitats for one species, we may well be unintentionally negatively affecting others. To our knowledge, there are no previous records of Burrowing Owls having been found as prey items in Saskatchewan GHOW nests. Most notably, C.S. Houston has no record of Burrowing
Owls as prey in 2922 GHOW nest visits made between 1960 and 1992 (pers. comm.).

Our data demonstrate impressive variety in the diet of the GHOW in Saskatchewan. The diversity we observed is likely an underestimate of the true diet of these birds, given that our sampling method produces a bias exaggerating the importance of larger prey. Smaller prey such as mice, voles, and Least Weasels* are likely swallowed whole by the owls soon after they arrive at the nest, and would therefore be underrepresented in our analysis. In addition, we only sampled prey items from each nest on one day, and our total effort spans only a small fraction of the year. Thus, we cannot detect seasonal changes in diet. While very interesting and informative, our diet analysis presents a limited perspective on GHOW prey.

\section{Acknowledgements}

We thank all of the nest finders and field helpers as well as Ray Poulin for his map of the 2008 nest locations.

*EDITORS' NOTE: A photograph of a Least Weasel found in a GHOW nest was published in Blue Jay 66(2):66. 